\title{
DAYA INSEKTISIDA DAN DAYA REPELLENT EKSTRAK DAUN JERUK PURUT (Citrus hystrix D.C) TERHADAP HAMA GUDANG Sitophilus zeamais Motschulsky
}

\section{The Insecticide Toxicity and Repelling Ability of Jeruk Purut (Citrus hystrix D.C) Leaf Extract on Maize Weevil (Sitophilus zeamais Motsch)}

\author{
Alfia Wulansari ${ }^{1 \mathrm{a}}$, Nur Rochman ${ }^{2}$, dan Setyono ${ }^{2}$ \\ ${ }^{1}$ Mahasiswa Program Studi Agroteknologi, Fakultas Pertanian, Universitas Djuanda Bogor. \\ ${ }^{2}$ Staf Pengajar Program Studi Agroteknologi, Fakultas Pertanian, Universitas Djuanda Bogor \\ "Jl Tol Ciawi No 1 Kotak Pos 3516720 \\ ${ }^{\mathrm{a} E-m a i l: a l f i a . w u l a n s a r i @ u n i d a . a c . i d}$
}

\begin{abstract}
ABSTRAK
Hama gudang Sitophilus zeamais Motschulsky adalah hama primer yang merusak jagung di dalam gudang penyimpanan. Pengendalian S. zeamais dapat dilakukan dengan penggunaan pestisida nabati. Penelitian ini bertujuan untuk mengetahui kemampuan daun jeruk purut sebagai pestisida nabati yang mematikan dan menolak kehadiran hama gudang Sitophilus zeamais Motschulsky. Kegiatan penelitian dilaksanakan di Laboratorium Entomologi Seameo Biotrop pada bulan Maret - Agustus 2018. Kegiatan penelitian meliputi dua percobaan, masing-masing menggunakan rancangan acak lengkap (RAL) dengan tiga kali ulangan pada setiap konsentrasi ekstrak daun jeruk purut. Konsentrasi yang diaplikasikan pada uji pendahuluan daya insektisida adalah $0 \%, 2 \%, 4 \%, 6 \%$ dan $8 \%$ dan pada uji pendahuluan daya repellent adalah $1 \%, 2 \%, 4 \%, 6 \%$ dan $8 \%$. Konsentrasi yang diaplikasikan pada uji utama daya insektisida dan daya repellent adalah $3 \%, 6 \%, 9 \%, 12 \%$ dan 15\%. Mortalitas tertinggi S. zeamais di antara konsentrasi yang dicoba sebesar $82,2 \%$ terdapat pada $15 \%$ pada 72 JSP (jam setelah perlakuan). Penolakan tertinggi $S$. zeamais di antara konsentrasi yang dicoba sebesar $95 \%$ terdapat pada $9 \%$ pada 24 JSP dan termasuk efektifitas yang baik. Hasil penelitian menunjukkan bahwa daun jeruk purut lebih berpotensi sebagai insektisida dibanding repellent pada hama gudang Sitophilus zeamais Motschulsky.
\end{abstract}

Kata kunci: Pestisida nabati, Pengendalian nabati, Penolak, Insektisida, Kumbang bubuk

\section{ABSTRACT}

Sitophilus zeamais Motsch. is a primary storage insect pest damaging maize grains. Control of S. zeamais can be done by applying biopesticide. This study was aimed at assessing the ability of Jeruk Purut leaf extract, as biopesticide, to kill and repel Sitophilus zeamais Motsch. The study was conducted at Entomology Laboratory, Seameo Biotrop in March to August 2018. A completely randomized design with three replicates in each rate of Jeruk Purut leaf extract was used. In preliminary pesticide toxicity experiment, five rates of Jeruk Purut leaf extract, namely $0 \%, 2 \%, 4 \%, 6 \%$, and $8 \%$ were applied. In preliminary repelling ability experiment, five rates of Jeruk Purut leaf extract, namely 1\%, 2\%, 4\%, 6\%, and 8\% were applied. In the main pesticide toxicity and repelling ability trial, five rates of Jeruk Purut leaf extract, namely 3\%, 6\%, 9\%, 12\%, and $15 \%$ were applied. Results showed that in 24 hour after treating (HAT) no significant effects were found. Significant effects of Jeruk Purut leaf extract as insecticide on S. zeamais were found in 48 and 72 HAT. The highest mortality rate (82.2\%) of S. zeamais was found in $15 \%$ rate of Jeruk Purut leaf extract in 72 HAT. The application of Jeruk Purut leaf extract was not found to give significant effects on repelling S. zeamais in 24, 48, and 72 HAT as indicated in their sharply fluctuating repellent values. The highest repelling ability (95\%) was found in the application of 9\% Jeruk Purut leaf extract in 24 HAT. It was concluded that Jeruk Purut leaf extract was more potential as insecticide repellent for Sitophilus zeamais Motsch.

Key words: biopesticide, repellent, insecticide, maize, primary storage insect pest 


\section{PENDAHULUAN}

Jagung merupakan salah satu komoditas yang memiliki peran dalam pembangunan sektor pertanian (Ningsih et al. 2017). Jagung memiliki banyak manfaat di antaranya sebagai bahan pangan, pakan, industri dan sebagai bahan bakar alternatif (biofuel) (Balitbangtan 2015). Produksi jagung di Indonesia pada tahun 2015 mencapai 19.612.435 ton meningkat dari tahun 2014 yang hanya mencapai 19.008.426 ton (BPS 2017). Angka tersebut diperkirakan akan terus meningkat seiring dengan bertambahnya kesadaran masyarakat akan berbagai manfaat dari jagung. Peningkatan produksi jagung diiringi dengan penurunan kualitas selama di penyimpanan karena serangan hama gudang atau Sitophilus zeamais Motschulsky.

Kerusakan jagung akibat serangan hama gudang mencapai $30-100 \%$ (Nonci dan Muis 2015). Untuk mengurangi kerugian dilakukan pengendalian dengan menggunakan pestisida sintetik. Penggunaan pestisida sintetik membawa dampak negatif seperti hama utama menjadi resisten dan residu yang tersisa akan menjadi toksik apabila masuk ke dalam rantai makanan (Ramlan dan Supartinah 2002). Oleh sebab itu perlu adanya alternatif pengendalian yang dapat menekan hama gudang Sitophilus zeamais yang bersifat ramah lingkungan, salah satu alternatif tersebut dengan penggunaan pestisida nabati. Pestisida nabati adalah pestisida yang berasal dari tumbuhan. Asmaliah et al. (2010) menyatakan bahwa jeruk purut merupakan tumbuhan yang dapat dijadikan sebagai pestisida nabati karena kandungan metabolit sekundernya. Daun jeruk purut (Citrus hystrix D.C) memiliki kandungan metabolit sekunder yaitu minyak atsiri, flavonoid, fenolik, steroid, terpenoid, alkaloid dan kumarin (Rahmi et al. 2013) yang dapat dijadikan sebagai bahan pestisida nabati.

Penelitian ini bertujuan untuk mengetahui kemampuan daya insektisida dan daya repellent ekstrak daun jeruk purut (Citrus hystrix D.C) sebagai pestisida nabati terhadap hama gudang Sitophilus zeamais Motschulsky, serta dapat diperoleh konsentrasi yang mematikan 50\% hama
$\left(\mathrm{LC}_{50}\right)$ dan $95 \%$ hama $\left(\mathrm{LC}_{95}\right)$ juga konsentrasi yang dapat menolak kehadiran hama $80 \%$.

\section{BAHAN DAN METODE}

Penelitian Penelitian dilaksanakan pada bulan Maret hingga Agustus 2018 di Laboratorium Entomologi, SEAMEO BIOTROP, Jl. Raya Tajur km 6, Bogor. Alatalat yang digunakan selama penelitian adalah tempat pengembang-biakan serangga, tempat pengujian, selang, kertas saring, rotatory evaporator, solder, gelas ukur, erlenmeyer, corong, pipet, dan kertas saring. Bahan-bahan yang digunakan selama penelitian adalah hama gudang Sitophilus zeamais, jagung, daun jeruk purut, dan etanol $96 \%$.

\section{Rearing Hama Gudang Sitophilus zeamais}

Rearing adalah pengembangbiakan
hama. Rearing dilakukan dengan
menginfestasikan imago hama gudang
Sitophilus zeamais. Hama didapatkan dari
Laboratorium Entomologi Seameo Biotrop.
Sebanyak 100 ekor hama gudang S. zeamais
dimasukkan ke dalam toples yang sudah diisi
250 g jagung. Jagung berfungsi sebagai pakan
dan media berkembang biak, kemudian toples
disimpan selama \pm 6 minggu dengan suhu
ruangan. Pada minggu kedua dilakukan
pemisahan imago indukan pada media lain.
Serangga yang dipakai pada pengujian adalah
serangga turunan pertama.

\section{Pembuatan Pestisida Nabati}

Daun jeruk purut sebanyak $5 \mathrm{~kg}$ dibersihkan dan dikeringkan. Daun jeruk kemudian dihancurkan hingga halus. Bahan yang sudah halus dimaerasi dengan menggunakan pelarut etanol $96 \%$ selama tiga jam, kemudian disaring dengan menggunakan corong dan kertas saring sehingga menghasilkan filtrat yang jernih. Larutan dipekatkan menggunakan alat rotary evaporator pada suhu $45^{\circ} \mathrm{C}$ sehingga dihasilkan hasil ekstrak yang kental. Hasil ekstrak disimpan pada lemari pendingin sampai pengujian dilakukan.

\section{Uji Daya Insektisida}

Konsentrasi yang diaplikasikan pada uji pendahuluan adalah $0 \%, 2 \%, 4 \%, 6 \%$, dan 
8\%. Setiap konsentrasi menggunakan tiga ulangan sehingga terdapat 15 satuan percobaan. Konsentrasi yang diaplikasikan pada uji utama daya insektisida adalah $3 \%$, $6 \%, 9 \%, 12 \%$, dan $15 \%$. Setiap konsentrasi menggunakan tiga ulangan sehingga terdapat 15 satuan percobaan. Ekstrak jeruk purut dilarutkan dengan pelarut sesuai konsentrasi, pelarut yang digunakan adalah etanol $96 \%$. Larutan ekstrak dioleskan pada kertas saring Whatman secara merata kemudian dikeringanginkan. Kertas saring ditempelkan pada cawan kemudian dimasukkan 30 ekor imago $S$. zeamais pada cawan kemudian cawan ditutup. Pengamatan dilakukan dengan menghitung jumlah $S$. zeamais yang mati pada 24 jam setelah perlakuan (JSP), 48 JSP, dan 72 JSP.

\section{Uji Daya Repellent}

Konsentrasi yang diaplikasikan pada uji pendahuluan adalah $1 \%, 2 \%, 4 \%, 6 \%$, dan $8 \%$. Setiap konsentrasi menggunakan tiga ulangan sehingga terdapat 15 satuan percobaan. Konsentrasi yang diaplikasikan pada uji utama daya repellent adalah $3 \%, 6 \%$, $9 \%$, $12 \%$, dan 15\%. Setiap konsentrasi menggunakan tiga ulangan sehingga terdapat 15 satuan percobaan. Pelarut yang digunakan adalah etanol 96\%. Sebanyak $45 \mathrm{~g}$ jagung direndam sesuai konsentrasi masing-masing selama 1 menit kemudian dikeringkan, sementara untuk kontrol $45 \mathrm{~g}$ jagung hanya direndam pada pelarut etanol $96 \%$. Tempat pengujian berupa toples yang diberi lubang pada salah satu sisinya dengan diameter 1,5 $\mathrm{cm}$. Antara toples pertama dengan toples kedua dengan dihubungkan menggunakan selang yang berdiameter $1,5 \mathrm{~cm}$, pada toples kedua dengan toples ketiga juga dihubungkan dengan selang dengan diameter $1,5 \mathrm{~cm}$. Sebanyak $15 \mathrm{~g}$ jagung yang sudah diberikan perlakuan dimasukkan ke dalam toples pertama, $15 \mathrm{~g}$ jagung kontrol dimasukkan pada toples ketiga, imago $S$. zeamais sebanyak 30 ekor dimasukkan ke dalam toples kedua. Pengamatan dilakukan dengan menghitung $S$. zeamais yang masuk pada toples perlakuan dan toples kontrol pada 24 JSP, 48 JSP, dan 72 JSP.

Rancangan percobaan yang dilakukan adalah rancangan acak lengkap (RAL) yang terdiri dari satu faktor yaitu ekstrak daun jeruk purut sebagai pestisida nabati. Pada penelitian ini akan dilakukan dua percobaan, yaitu percobaan ekstrak daun jeruk purut sebagai insektisida yang mematikan hama dan ekstrak daun jeruk sebagai repellent yang menolak kehadiran hama.

Rumus persentase kematian adalah:

$$
\mathbf{P}=\frac{\mathrm{n}}{\mathrm{N}} \mathbf{x} 100 \%
$$

Keterangan:

$\mathrm{P} \quad=$ Persentase kematian

$\mathrm{n} \quad=$ Jumlah individu yang mati

$\mathrm{N} \quad=$ Jumlah individu yang digunakan

Rumus persentase penolakan adalah:

Keterangan:

$$
\mathrm{X}=\frac{\mathrm{k}}{\mathrm{p}+\mathrm{k}} \times 100 \%
$$

$\mathrm{p} \quad=$ jumlah serangga yang masuk ke dalam wadah perlakuan

$\mathrm{k}=$ jumlah serangga yang masuk ke dalam wadah tanpa perlakuan

$\mathrm{X}=$ Presentase rata-rata penolakan

Keefektifan daya repellent dapat ditentukan dengan kriteria sebagai berikut:

Baik $\quad: x \geq 80 \%$

Kurang baik $: x<60 \%$

Cukup baik $\quad: 60 \% \leq \mathrm{x}<80 \%$

\section{HASIL DAN PEMBAHASAN}

\section{Uji Pendahuluan Daya Insektisida Ekstrak Daun Jeruk Purut}

Hasil uji pendahuluan menunjukkan adanya peningkatan mortalitas (kematian) hama jagung Sitophilus zeamais pada 24, 48, dan 72 JSP. Mortalitas tertinggi pada uji pendahuluan sebesar $55,6 \%$ terjadi pada konsentrasi $8 \%$ pada 72 JSP dan mortalitas terendah sebesar $0 \%$ terjadi pada konsentrasi $0 \%$ pada 24 JSP (Gambar 1). 


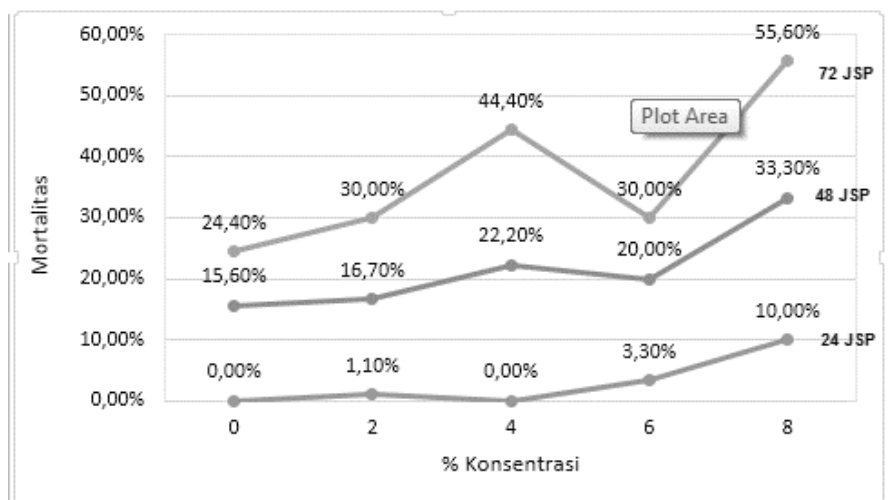

Gambar 1 Rata-rata mortalitas hama gudang Sitophilus zeamais pada uji pendahuluan

\section{Uji Utama Daya Insektisida Ekstrak Daun Jeruk Purut}

Konsentrasi yang diaplikasikan pada uji utama yaitu $3 \%, 6 \%, 9 \%, 12 \%$, dan $15 \%$ (v/v). Dari konsentrasi tersebut didapatkan hasil mortalitas tertinggi sebesar 82,2\% terjadi pada $15 \%$ pada 72 JSP. Mortalitas terendah terdapat pada konsentrasi $3 \%$ yang hanya mencapai 3,30\% pada 24 JSP (Gambar 2). Ekstrak daun jeruk purut pada 24 JSP tidak memiliki pengaruh yang nyata sehingga tidak dapat dilakukan analisis regresi. Berbeda dengan 48 JSP dan 72 JSP yang memiliki pengaruh nyata sebagai insektisida Sitophilus zeamais sehingga perlu dilakukan analisis regresi.

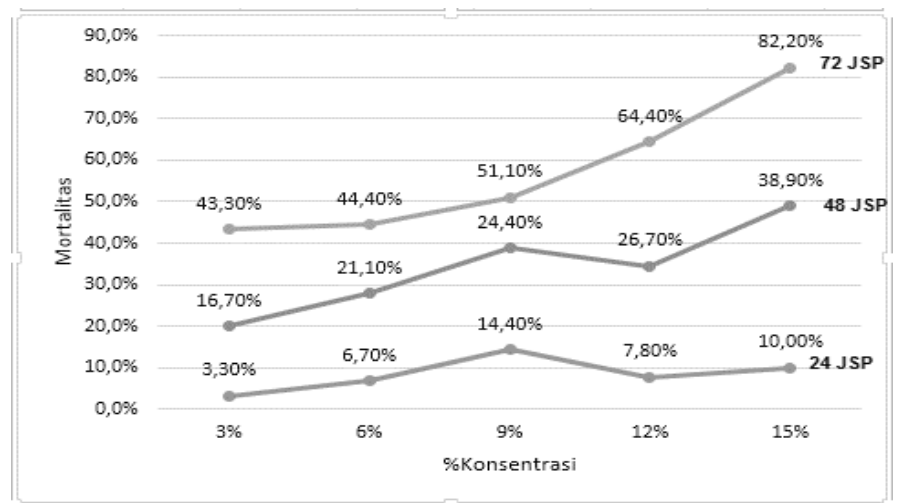

Gambar 2 Rata-rata mortalitas hama gudang Sitophilus zemais pada uji utama

Mortalitas hama S. zeamais pada 48 JSP disajikan pada Gambar 3 dan menunjukkan hasil yang signifikan. Hubungan mortalitas dengan konsentrasi ekstrak daun jeruk purut pada 48 JSP menghasilkan suatu persamaan regresi linear dengan $\mathrm{y}=1,6667 \mathrm{x}+0,1056$ dengan $\mathrm{R}^{2}=$ 0,791. Berdasarkan persamaan tersebut mortalitas maksimal tidak dapat dicari karena persamaan berbentuk regresi linear, sementara apabila mencari $\mathrm{LC}_{50}$ dibutuhkan konsentrasi sebesar $24 \%$ dan mencari $\mathrm{LC}_{95}$ dibutuhkan konsentrasi sebesar $51 \%$. Berdasarkan hasil tersebut, maka $\mathrm{LC}_{50}$ dan $\mathrm{LC}_{95}$ pada 48 JSP belum dicapai pada konsentrasi yang diterapkan. 


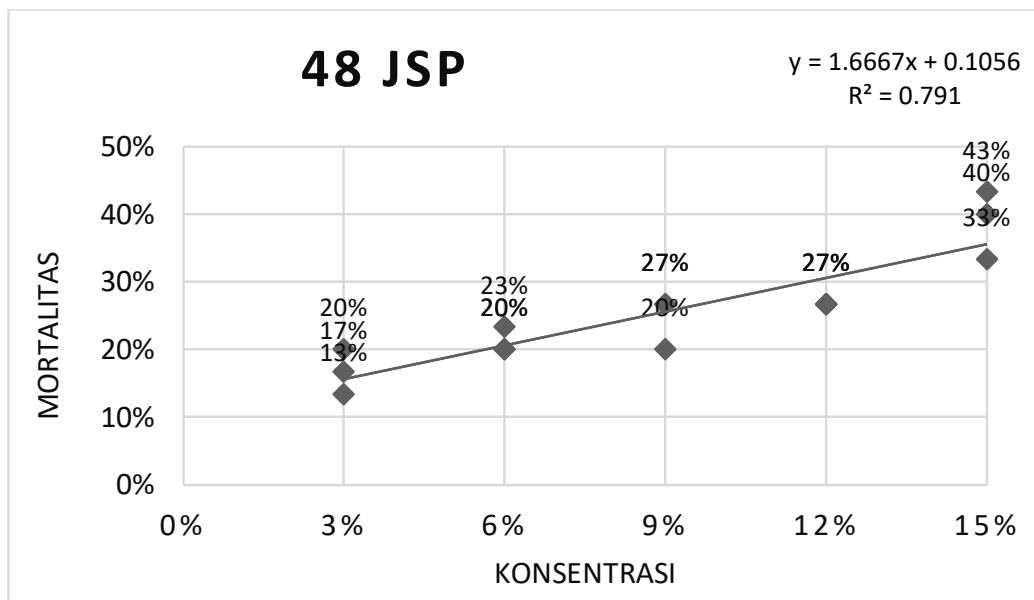

Gambar 3 Persamaan regresi pada 48 JSP Uji Utama

Mortalitas hama S. zeamais pada 72

JSP disajikan pada Gambar 4 dan menunjukkan hasil yang signifikan. Hubungan mortalitas dengan konsentrasi ekstrak daun jeruk purut pada 72 JSP menghasilkan suatu suatu persamaan regresi linear dengan $\mathrm{y}=3,2593 \mathrm{x}+0,2778$ dengan $\mathrm{R}^{2}=0,7381$. Berdasarkan persamaan tersebut mortalitas maksimal tidak dapat dicari karena persamaan berbentuk regresi linear, sementara apabila mencari $\mathrm{LC}_{50}$ dibutuhkan konsentrasi sebesar 7\% dan mencari $\mathrm{LC}_{95}$ dibutuhkan konsentrasi sebesar $21 \%$. Berdasarkan hasil tersebut maka $\mathrm{LC}_{50}$ sudah dapat dicapai dan $\mathrm{LC}_{95}$ pada 72 JSP belum dicapai pada konsentrasi yang diterapkan.

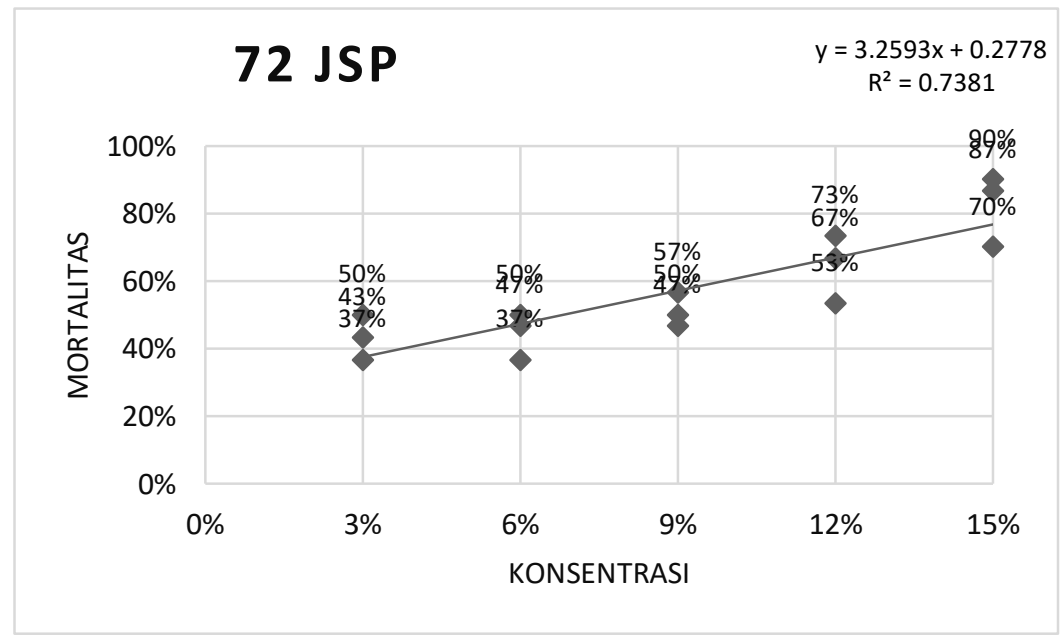

Gambar 4 Persamaan regresi pada 72 JSP uji utama

\section{Uji Pendahuluan Daya Repellent Ekstrak Daun Jeruk Purut}

Hasil uji pendahuluan daya repellent ekstrak daun jeruk purut terhadap hama jagung Sitophilus zeamais pada 24, 48, dan 72 jam setelah perlakuan (JSP) ditunjukkan pada Gambar 5. Daya repellent pada 24 JSP memiliki grafik dengan angka yang berfluktuatif tajam. Rata-rata daya repellent pada 24 JSP mencapai $68 \%$ pada konsentrasi $1 \%$, kemudian turun menjadi $51 \%$ pada konsentrasi $2 \%$ kemudian turun kembali menjadi $41 \%$ pada konsentrasi $4 \%$, dan naik menjadi $83 \%$ pada konsentrasi $6 \%$ dan turun kembali menjadi $43 \%$ pada konsentrasi $8 \%$. Sementara pada 48 dan 72 JSP cenderung memiliki alur grafik yang sama meski dengan angka yang berbeda. Daya repellent tertinggi pada 48 JSP terjadi pada konsentrasi $4 \%$ yaitu sebesar $75,91 \%$ dan terendah pada konsentrasi $1 \%$ yaitu $39,46 \%$. Sementara itu daya repellent tertinggi pada 72 JSP mencapai $84,85 \%$ terjadi pada konsentrasi $6 \%$ dan terendah hanya mencapai $52,24 \%$ terjadi pada konsentrasi $1 \%$. 


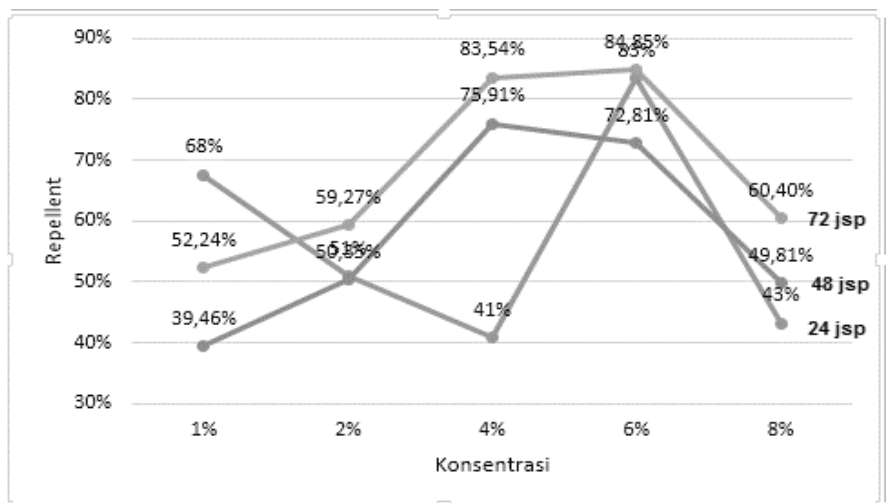

Gambar 5 Rata-rata daya repellent hama gudang Sitophilus zeamais pada uji pendahuluan

\section{Uji Utama Daya Repellent Ekstrak Daun Jeruk Purut}

Konsentrasi yang diaplikasikan pada uji utama yaitu 3\%, 6\%, 9\%, 12\%, dan $15 \%$ (v/v). Dari konsentrasi tersebut didapatkan hasil daya repellent tertinggi sebesar 95\% dengan konsentrasi $9 \%$ pada 24 JSP. Daya repellent terendah terdapat pada konsentrasi $15 \%$ yang hanya mencapai $24 \%$ pada 48 JSP (Gambar 6). Pengaruh ekstrak daun jeruk purut pada 24 JSP, 48 JSP, dan 72 JSP tidak memiliki pengaruh yang nyata sebagai repellent Sitophilus zeamais, sehingga tidak diperlukan analisis regresi pada ketiga JSP tersebut.

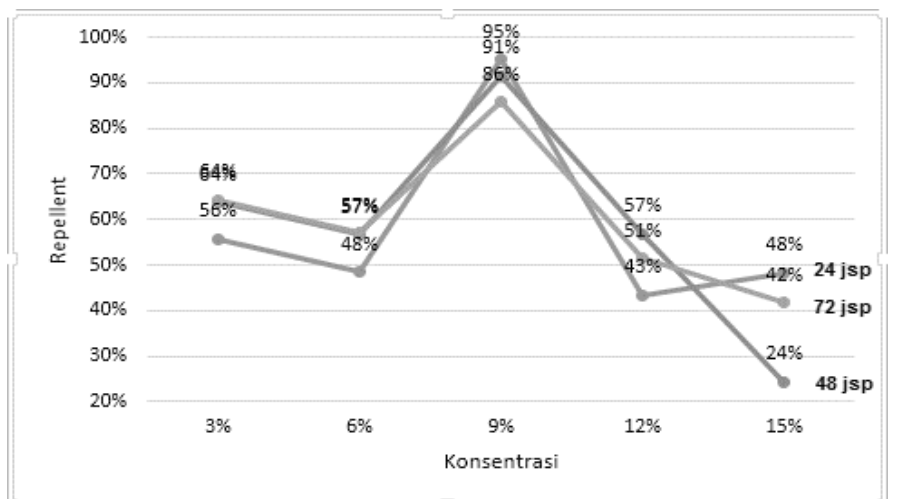

Gambar 6 Rata-rata daya repellent pada 24 JSP, 48 JSP dan 72 JSP pada uji utama.

Tabel 1 Hasil uji utama

\begin{tabular}{llll}
\hline \multirow{2}{*}{ Konsentrasi } & \multicolumn{3}{c}{ Repellent (\%) } \\
\cline { 2 - 4 } & 24 JSP & 48 JSP & 72 JSP \\
\hline $3 \%$ & $56^{*}$ & $64^{* *}$ & $64^{* *}$ \\
$6 \%$ & $48^{*}$ & $57^{*}$ & $57^{*}$ \\
$9 \%$ & $95^{* * *}$ & $91^{* * *}$ & $86^{* * *}$ \\
$12 \%$ & $43^{*}$ & $57^{*}$ & $51^{*}$ \\
$15 \%$ & $48^{*}$ & $24^{*}$ & $42^{*}$ \\
\hline Rata-rata & $58^{*}$ & $58,6^{*}$ & $60^{* *}$ \\
\hline
\end{tabular}

Keterangan: Tingkat efektifitas repellent $\left(* * *=\right.$ Baik, ${ }^{* *}=$ Cukup baik, $*=$ Kurang baik) 
Berdasarkan Tabel 1 tingkat keefektifan repellent daun jeruk purut terhadap $S$. zeamais kurang baik, terlihat dari banyaknya persentase repellent di bawah $60 \%$. Persentase repellent $60 \%-80 \%$ atau efektifitas cukup baik hanya terdapat pada konsentrasi $3 \%$ pada 48 JSP dan 72 JSP. Persentase repellent di atas $80 \%$ atau efektifitas baik hanya terdapat pada konsentrasi $9 \%$ pada 24,48 , dan 72 JSP. Ratarata keefektifan repellent pada 24 dan 48 JSP kurang baik, sedangkan pada 72 JSP cukup baik.

\section{Pembahasan}

Berdasarkan penelitian yang telah dilakukan Sitophilus zeamais termasuk ke dalam hama yang sangat aktif bergerak dan menyerang biji jagung. Selama masa rearing (pengembangbiakan hama) selama \pm 6 minggu, jagung sebagai media tempat tumbuh hama berlubang dan perlahan menjadi hancur/bubuk. Tandiabang (2007) menyatakan bahwa $S$. zeamais disebut sebagai kumbang bubuk, dan dikategorikan ke dalam hama utama (primary pest) yaitu hama yang mampu makan keseluruhan biji yang sehat dan menyebabkan kerusakan.

Pestisida nabati adalah pestisida yang berasal dari tumbuhan. Tumbuhan memiliki metabolit sekunder yang berfungsi sebagai pertahanan dari serangan organisme pengganggu (Asmaliyah et al. 2010). Dalam penelitian ini organisme penggangu yang menjadi sasaran adalah hama gudang Sitophilus zeamais. Keunggulan pestisida nabati yaitu pembuatannya murah dan mudah untuk dilakukan dalam skala kecil (rumah tangga), tidak meninggalkan efek negatif bagi lingkungan (Saenong 2016). Jeruk purut mengandung berbagai macam metabolit sekunder sehingga pada penelitian ini daun jeruk purut yang berhasil di ekstrak berwarna hijau tua sampai kehitaman. Warna tersebut berasal dari pigmen klorofil dan pigmen lainnya dalam daun yang dilarutkan oleh etanol (Munawaroh dan Handayani 2010).

Pengujian daya insektisida ekstrak daun jeruk purut terhadap hama gudang Sitophilus zeamais mengalami kenaikan mortalitas seiring dengan meningkatnya konsentrasi dan waktu pengamatan (24, 48 dan
72 JSP). Mortalitas pada uji pendahuluan tertinggi mencapai $55,6 \%$ terjadi pada konsentrasi $8 \%$ pada 72 JSP.

Uji pendahuluan dengan konsentrasi yang dicoba hanya mencapai $\mathrm{LC}_{50}$, sehingga perlu dilakukan uji utama untuk mendapatkan LC $_{95}$. Hasil dari uji utama menunjukan hal yang hampir serupa dengan uji pendahuluan, bahwa terjadinya peningkatan rata-rata mortalitas seiring dengan adanya peningkatan konsentrasi meski pada JSP tertentu terdapat penurunan rata-rata mortalitas hama.

Peningkatan mortalitas seiring dengan peningkatan konsentrasi menunjukkan bahwa semakin banyak daun jeruk purut yang dipakai sebagai pestisida nabati, maka semakin efektif dalam mematikan hama. Sitronelal pada minyak atsiri daun jeruk purut memiliki aktivitas sebagai bahan insektisida dan bersifat racun kontak dengan serangga (Lestari et al 2015). Racun kontak adalah terjadinya kematian hama/serangga akibat terjadinya kontak fisik serangga dengan insektisida (Joharina dan Alfiah 2012). Prosedur pengujian berupa cawan yang di dalamnya terdapat kertas saring yang telah dioleskan ekstrak daun jeruk purut, kemudian dimasukan $S$. zeamais membuat terjadinya kontak antara hama dengan kertas saring sehingga terjadi kematian pada hama. Pada penelitian ini dari konsentrasi yang telah dicoba belum bisa mencapai mortalitas $95 \%$ dan hanya bisa mencapai mortalitas $80 \%$. Hal ini diduga karena kandungan sitronelal yang dihasilkan pada saat ekstraksi tidak banyak karena menggunakan pelarut etanol. Penelitian Munawaroh dan Handayani (2010) menyatakan bahwa pelarut etanol menghasilkan kadar sitronelal dari ekstrak jeruk purut sebanyak $65,99 \%$ lebih sedikit dibanding menggunakan pelarut N-heksana dengan kadar sitronelal sebanyak 97,27\%.

Pengujian daya repellent ekstrak daun jeruk purut terhadap hama gudang Sitophilus zeamais pada uji pendahuluan dan uji utama mengalami nilai repellent yang berfluktuatif selama pengamatan 24, 48, dan 72 JSP. Persentase repellent yang berfluktuatif tajam membuat hasil pada 24, 48, dan 72 JSP pada uji utama tidak berpengaruh nyata, sehingga tidak bisa dilakukan analisis regresi. 
Minyak atsiri sebagai metabolit sekunder utama pada daun jeruk purut memiliki kelemahan terutama dalam hal stabilitas dan efektifitasnya (Hartati 2012). Karena stabilitas yang masih kurang optimal menjadi penyebab fluktuasi nilai penolakan hama pada uji repellent. Penurunan daya repellent yang terjadi diduga disebabkan karena karakter minyak atsiri yang mudah menguap (Shinta 2012) sehingga semakin lama maka kemampuan repellent akan semakin menurun. Faktor lain penyebab fluktuasi pada daya repellent adalah prosedur pengujian yang belum efektif, sehingga menyebabkan $S$. zeamais yang sudah berada di toples kontrol dapat bergerak bebas menuju toples perlakuan dan sebaliknya, dengan begitu data yang didapat menjadi fluktuatif.

\section{KESIMPULAN}

\section{Kesimpulan}

Mortalitas tertinggi $S$. zeamais di antara konsentrasi yang dicoba sebesar $82,2 \%$ terdapat pada $15 \%$ pada 72 JSP. Penolakan tertinggi $S$. zeamais di antara konsentrasi yang dicoba sebesar $95 \%$ terdapat pada $9 \%$ pada 24 JSP dan termasuk efektifitas yang baik. Hasil penelitian menunjukkan bahwa daun jeruk purut lebih berpotensi sebagai insektisida dibanding repellent pada hama gudang Sitophilus zeamais Motschulsky.

\section{Saran}

1. Perlu dilakukan prosedur pengujian yang lebih efektif untuk daya repellent.

2. Perlu dilakukan penelitian yang lebih lanjut mengenai metode atau cara pengaplikasian pestisida nabati ekstrak daun jeruk purut.

\section{DAFTAR PUSTAKA}

Asmaliyah, Wati H, Utami S, Mulyadi K, Yudhistira, dan Sari FW. 2010. Pengenalan Tumbuhan Penghasil Pestisida Nabati dan Pemanfaatannya Secara Tradisional. Jakarta: Kementerian Kehutanan.

Balitbangtan [Badan Penelitian dan Pengembangan Pertanian]. 2015.
Outlook Komoditas Pangan Strategis. Bogor: Balitbangtan.

BPS [Badan Pusat Statistik] 2017. Produksi Jagung di Indonesia. [Online] http://www.bps.go.id [Di akses 09 Januari 2018].

Hartati SY. 2012. Prospek pengembangan minyak atsiri sebagai pestisida nabati. Jurnal Perspektif. 11 (1): $45 \quad-58$.

Joharina AS, Alfiah S. 2012. Analisis deskriptif insektisida rumah tangga yang beredar di masyarakat. Jurnal Vektora. 4 (1): $23-32$.

Lestari S, Jayuskal A, dan Indrayanu Y. 2015. Bioaktivitas minyak atsiri daun jeruk purut (Citrus hystrix) terhadap rayap tanah (Coptotermes Sp.). JKK 4(4). 83 88.

Ningsih Y, Salbiah D, dan Sutikno A. 2007. Uji beberapa konsentrasi tepung daun gamal (Gliricidia sepium Jacq.) terhadap hama Sitophilus zeamais M. pada biji jagung di penyimpanan. JOM Faperta UR. 4 (1). Pekanbaru: Jurusan Agroteknologi - Universitas Riau.

Nonci N, Muis A. 2015. Biologi, Gejala Serangan, dan Pengendalian Hama Bubuk Jagung Sitophilus zeamais Motschulsky (Coleoptera: Curculionidae). Maros: Balai Penelitian Tanaman Serelia.

Munawaroh S, Handayani PA. 2010. Ekstraksi minyak daun jeruk purut (Citrus hystrix DC.) dengan pelarut etanol dan nheksana. Jurnal Kompetensi Teknik. 2(1): 73-78.

Rahmi U, Manjang Y dan Santoni A. 2013. Profil fitokimia metabolit sekunder dan uji aktivitas antioksidan tanaman jeruk purut (citrus histrix DC) dan jeruk bali (Citrus maxima (burm.f.) merr). Jurnal Kimia Unand. 2(2): 109 - 114.

Ramlan A, Supartinah I. 2002. Eksplorasi formasi keanekaragaman jenis, potensi dan pemanfaatan tumbuhan bahan pestisida alami di provinsi Jawa Barat dan Banten. Berita Biologi. 6 (3): 393 -400 . 
Saenong MS. 2016. Tumbuhan Indonesia potensial sebagai insektisida nabati untuk mengendalikan hama kumbang bubuk jagung (Sitophilus spp.). Jurnal Litbang Pertanian. 35 (3): $131-142$.

Shinta. 2012. Potensi minyak atsiri daun nilam (Pogostemon cablin B.), daun babadotan (Ageratum conyzoides L), bunga kenanga (Cananga odorata hook F \& Thoms) dan daun kenanga (Rosmarinus officinalis L) sebagai repellant terhadap nyamuk Aedes aegypti L. Media Litbang Kesehatan. 22 (2): $61-69$.

Tandiabang, JA. Tenrirawe, dan Surtikanti. 2007. Pengelolaan hama pascapanen jagung dalam Jagung: Teknik Produksi dan Pengembangan. Maros: Balai Penelitian Serealia. 